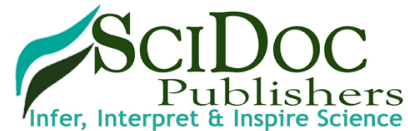

International Journal of Reproduction, Fertility \& Sexual Health (IJRFSH) ISSN: $2377-1887$

\title{
Cytotoxic Effect of Radiographic Fixer Effluent on Testicular Tissues of Wistar Rats
}

\author{
Research Article \\ Ugwu C. Anthony ${ }^{1}$, Odoh O. Fidelis ${ }^{1}$, Dimkpa U²* Okeke M. Chijioke ${ }^{3}$, Okafor E. Christian ${ }^{3}$, Enemuo C. Ijeoma ${ }^{3}$, Okafor Izuchukwu ${ }^{3}$, Mmaju Chi- \\ $\operatorname{dimma} a^{2}$ \\ ${ }^{1}$ Department of Radiography, Faculty of Health Science and Technology, Nnamdi Azikiwe University, Nnewi Campus, Anambra State, Nigeria. \\ ${ }^{2}$ Physiology Department, Faculty of Basic Medical Sciences, Nnamdi Azikiwe University, Nnewi Campus, Anambra State, Nigeria. \\ ${ }^{3}$ Anatomy Department, Faculty of Basic Medical Sciences, Nnamdi Azikiwe University, Nnewi Campus, Nnewi, Anambra State, Nigeria.
}

\section{Abstract}

Background: Limited information exists concerning the cellular changes associated with the toxicity of fixer effluents on testicular tissues.

Objectives: The present study aimed at demonstrating the histopathological changes in the testicular tissues of Wistar rats following exposure to fixer effluent.

Materials and Methods: Eighteen young Wistar rats of weights 140-220g were divided into three groups - I (control), II and III. Each of the groups was further sub-divided into two groups of 3 rats each. The control groups (IA and IB) were orally administered with $1 \mathrm{ml}$ of distilled water daily for 14 days and 28 days respectively; the two sub-groups of group II rats (IIA and IIB) were administered with $200 \mathrm{mg} / \mathrm{kg}$, while those of group III (IIIA and IIIB) were administered $400 \mathrm{mg} / \mathrm{kg}$ of fixer effluent daily for 14 days and 28 days respectively.

Results: Histopathological findings indicated normal testicular tissues in the control groups IA and IB and groups IIA and IIIA respectively. In contrast, there were some histopathological changes in the testes in groups IIB and IIIB.

Conclusions: The present histological findings suggest that prolonged exposure to radiographic fixer effluent may cause a cytotoxic effect on the seminiferous tubules of the testes and this may impair germination, maturation, and transportation of the sperm cells within the male testes.

Keywords: Histopathology; Testes; Silver; Radiography; Wistar Rats.

\section{Introduction}

Fixer is a chemical used in processing photographic or x-ray films in radio-diagnostic centers [1]. It is applied after the developing phase to neutralize any developer remaining on the film and to remove undeveloped silver halides and harden the emulsion [1]. The silver halide solvent in ordinary fixers includes sodium thiosulfate and ammonium thiosulfate - a faster-acting silver halide solvent used in rapid fixers [2]. Ordinarily, fixers are harmless, but the longer and more frequently used, the more toxic they become [3]. The exhausted fixer effluent that is generated is considered a hazardous chemical waste due to the presence of silver complexes that can pose risks to public health or the environment. Fixer effluents are reported to cause irreversible damage to human health and contaminate the soil, water, and food if untreated before disposal or inappropriately disposed of [4]. In most developing countries, the treatment of effluents at most imaging diagnosis centers, including teaching and research institutions, is not appropriately performed. Often, these chemical wastes are directly discarded without any previous treatment, into the public sewer system [4]. This means that the effluents are discarded with a high chemical oxygen demand (COD) and hydrogenic potential $(\mathrm{pH})$, and color, total dissolved solids concentration, chlorides, sulfates and turbidity over allowed limits [5].

Globally, reproductive health problems appear to be on the rise and there is increasing concern that exposure to environmental contaminants may be linked with reproductive health and fertility problems in men. The male reproductive system is a complex process that involves the testes, epididymis, sex glands and associated hormones [6]. Almost all healthy male vertebrates have two testes [7], which are housed in a sac known as the scrotum

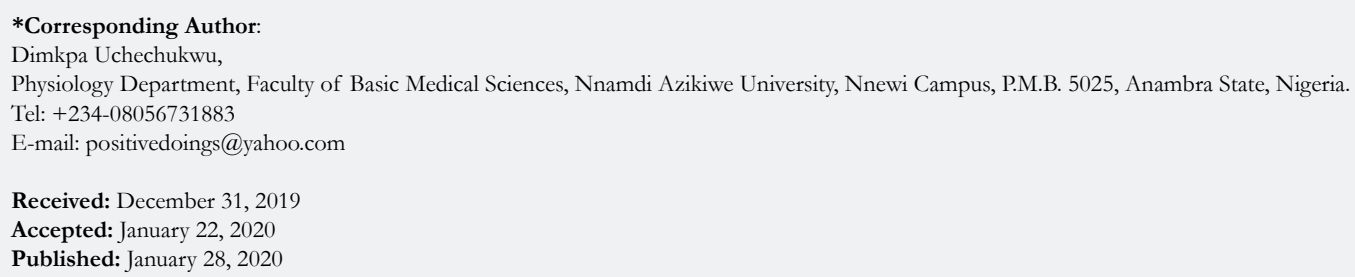

Copyright: Dimkpa Uchechukwu ${ }^{\circ}$ 2018. This is an open-access article distributed under the terms of the Creative Commons Attribution License, which permits unrestricted use, distribution and reproduction in any medium, provided the original author and source are credited. 
and separated by an incomplete septum. The testes perform two highly organized and intricate functions called spermatogenesis and steroidogenesis, which are crucial for the perpetuation of life [6]. Spermatogenesis is a highly dynamic and synchronized process which takes place in the seminiferous tubules of the testes with the support of somatic Sertoli cells, leading to the formation of mature spermatozoa from undifferentiated stem cells [6]. The interstitial compartment which comprises of the Leydig cells is the site for steroidogenesis in the testes [8].

Reproductive toxicants targeting the germ-line have the potential to cause alterations in spermatogenesis and fertility, subsequently affecting the reproduction rate and health of the offspring [9]. However, it is not known if exposure to radiographic fixer effluent may have harmful effects on the testes. The present study, therefore, is aimed at investigating the effect of fixer effluent on the histology of the testes of male Wistar rats.

\section{Materials and Methods}

\section{Animals}

Eighteen healthy Wistar rats weighing 140-220 g were used. They were housed in the animal house of the Department of Human Anatomy, Nnamdi Azikiwe University, Nnewi Campus, under standard conditions $\left(29 \pm 2{ }^{\circ} \mathrm{C}\right.$ temperature, $40-55 \%$ humidity, good ventilation) and had free access to water and diet (normal rat chow). They were acclimatized for two weeks before the start of the experiment.

\section{Test Chemical}

The original product, a commercially prepared fixer (a chemical used in processing photographic or x-ray films) was purchased from Bedgood Manufacturing Company Ltd, China. The main components of the fixer are sodium thiosulfate and ammonium thiosulfate. The content of the exhausted fixer effluent, the liquid waste material generated from radiographic processing, include silver, hydroquinone, quinine, methol, sodium thiosulfate, sodium sulfite, boric acid and cyanide, chloride, iron, total phosphorus, total nitrogen and sulfite concentrations. The lethal dose (LD50) concentration of the fixer effluent was calculated as $2450 \mathrm{mg} / \mathrm{kg}$ body weight using the formula: $\operatorname{LD} 50=\sqrt{\mathrm{a}} \mathrm{x} \mathrm{b}$ (where: $\mathrm{a}=$ the lowest dose that brought death i.e. 3000 and $b=$ the highest dose that did not kill i.e. 2000). The lethal dose test of the fixer effluent was carried out at the Faculty of Pharmacy and Pharmaceutical Sciences, Nnamdi Azikiwe University, Agulu Campus according to the method employed by Lorke [10]. The concentrations of the fixer effluent used for the experiment were sub-lethal doses of $200 \mathrm{mg} / \mathrm{kg}$ (lower dose) and $400 \mathrm{mg} / \mathrm{kg}$ (higher dose) of body weight.

\section{Experimental Design}

The present experiment was designed to be time and dose-dependent. The animals were divided randomly into three groups of 6 rats each based on the dose of fixer effluent administered to them - i.e. control group and experimental groups II (lower dose, $200 \mathrm{mg} / \mathrm{kg}$ ) and III (higher dose, $400 \mathrm{mg} / \mathrm{kg}$ ) respectively. The groups were further classified as either A or B of 3 rats each depending on the duration (14 or 28 days) of effluent adminis- tration. Thus control groups IA and IB were administered with distilled water for 14 and 28 days respectively; group IIA rats were administered with lower dose $(200 \mathrm{mg} / \mathrm{kg})$ of effluent for a short term period of 14 days; the group IIB rats were administered with the lower dose of effluent for a long term period of 28 days; group IIIA rats were administered with higher dose $(400 \mathrm{mg} / \mathrm{kg})$ of effluent for short term period of 14 days and; group IIIB rats were administered with higher dose of effluent for long term period of 28 days. The effluent administration was done by oral gavages. The average fixer effluent consumption was $0.2 \mathrm{ml} /$ day for the lower dose group and $0.42 \mathrm{ml}$ for the higher dose group. After 14 days, three rats from groups IA, IIA and IIIA were sacrificed (using the chloroform inhalation method), while the three rats from each of the remaining groups, IB, IIB, IIIB, were sacrificed after 28 days and their testes harvested.

\section{Tissue Preparation}

As soon as the animals were sacrificed, they were quickly dissected and their testes removed and immediately fixed in a fixative (Bouni's fluid) and transferred into specimen bottles and kept frozen for 48 hours before undergoing routine processing (dehydration, clearing, and infiltration with melted paraffin). The testicular tissues were embedded in paraffin wax, sectioned at $5 \mu \mathrm{m}$ placed on a hot water bath, after which they were dried and stained by hematoxylin and eosin. The photomicrographs were observed using Nikkon research microscope (Novex, Holland). The micrograph pictures were taken with a digital camera (DCM 510.5M Pixels, CMOS chip) connected to the microscope.

\section{Ethical Consideration}

All procedures used in this study conformed to the criteria and guiding principles for research involving animals as outlined in the "Guide for the Care and Use of Laboratory Animals " prepared by the National Academy of Sciences and published by the National Institutes of Health (NIH publication 86-23 revised 1985) [11]. The experiments were carried out following the ethical approval of the Ethical Board of Faculty of Health Science and Technology, College of Health Sciences, Nnamdi Azikiwe University.

\section{Results}

Figure 1 shows the photomicrograph of the testes of the control group $1 \mathrm{~A}$ indicating normal histology of the testes. The testicular tissues were intact with the seminiferous tubules, Sertoli cells with some spermatozoa and groups of Leydig cells in the interstitial connective tissue.

Figure 2 shows the photomicrograph of the testes of the control group 1B indicating normal histology of the testes. The testicular tissues were intact with the seminiferous tubules, Sertoli cells with some spermatozoa and groups of Leydig cells in the interstitial connective tissue.

Figure 3 shows the photomicrograph of the testes of rats with short term/low dose $(200 \mathrm{mg} / \mathrm{kg})$ administration of fixer effluent indicating normal Leydig cells, seminiferous tubules and the presence of sperm cells within the tubules. No significant histological changes occurred. 
The photomicrograph of testes of Wistar rats that received long term oral administration of low dose $(200 \mathrm{mg} / \mathrm{kg})$ fixer effluent indicated normal Leydig cells, seminiferous tubules with the presence of sperm cells within the tubules (Figure 4). Apart from enlarged connective tissues and reduced and irregular shaped sperm cells, no significant histological changes occurred.

The photomicrograph of the testes of Wistar rats that received short term oral administration of high dose $(400 \mathrm{mg} / \mathrm{kg})$ fixer ef- fluent presented with normal Leydig cells, seminiferous tubules with presence of few sperm cells within the tubules (Figure 5). No significant histological changes occurred.

The photomicrograph of testes of Wistar rats that received long term oral administration of high dose $(400 \mathrm{mg} / \mathrm{kg})$ fixer effluent indicated abnormal histology (Figure 6). The connective tissues degenerated, the seminiferous tubules were atrophic, and there was the loss of sperm cells within the tubules.

Figure 1. The photomicrograph of the testes of the control group (H \& E x100).

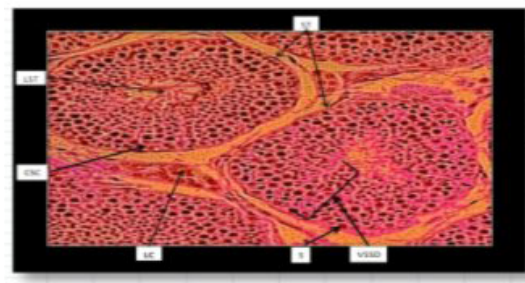

Abbreviations: ST, Seminiferous Tubule; LST, Lumen of the Seminiferous Tubule; CSC, Cytoplasm of Sertoli Cells, LC, Leydig Cells; S, Spermatogonium; VSSD, Varying Stages of Sperm Development.

Figure 2. The photomicrograph of the testes of the control group $1 \mathrm{~B}(\mathrm{H} \& \mathrm{E} \times 100)$.

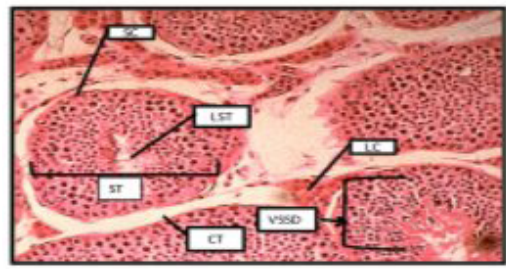

Abbreviations: ST, Seminiferous Tubule; LST, Lumen of the Seminiferous Tubule; LC, Leydig Cells; CT, Connective tissue; VSSD, Varying Stages of Sperm Development.

Figure 3. The photomicrograph of testes of rats administered short term/low dose (200mg/kg) fixer effluent (H \& $\mathrm{E} \times 100)$.

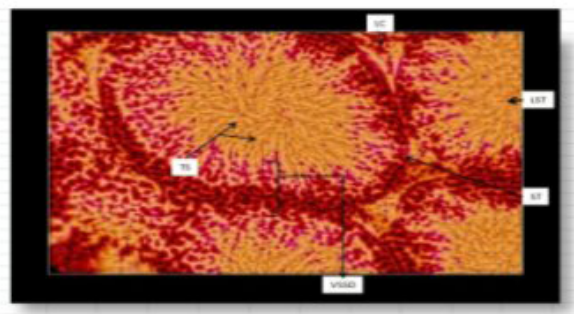

Abbreviations: ST, Seminiferous Tubule; LST, Lumen of the Seminiferous Tubule; LC, Leydig Cells; TS, Tails of Spermatozoa; VSSD, Varying Stages of Sperm Development.

Figure 4. The photomicrograph of testes of Wistar rats that received long term oral administration of low dose (200mg/ $\mathrm{kg})$ fixer effluent (H \& E x 100).

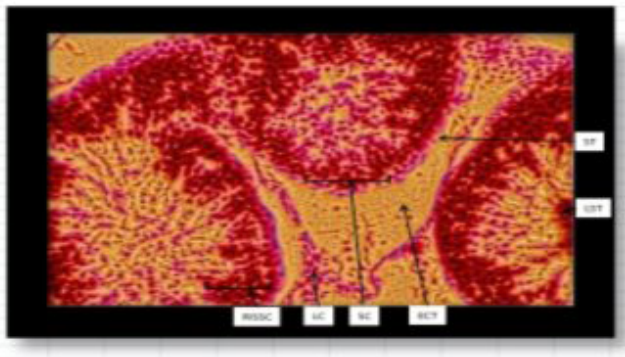

Abbreviations: ST, Seminiferous Tubule; LST, Lumen of the Seminiferous Tubule; LC, Leydig Cells; SC, Spermatogenic Cells; ECT, Enlarged Connective Tissues; RISSC, Reduced and Irregular Shaped Sperm Cells. 
Figure 5. The photomicrograph of the testes of Wistar rats that received short term oral administration of high dose (400mg/kg) fixer effluent (H \& E x 100).

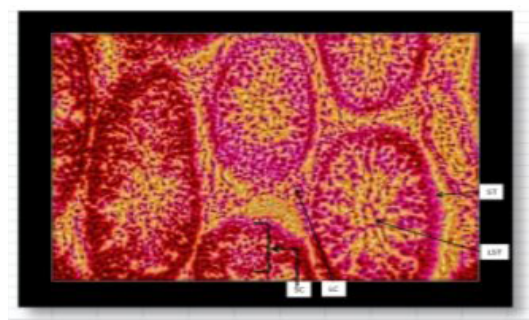

Abbreviations: ST, Seminiferous Tubule; LST, Lumen of the Seminiferous Tubule; LC, Leydig Cells; SC, Spermatogenic Cells.

Figure 6. The photomicrograph of testes of Wistar rats that received long term oral administration of high dose (400mg/ $\mathrm{kg}$ ) fixer effluent (H\&E x 400).

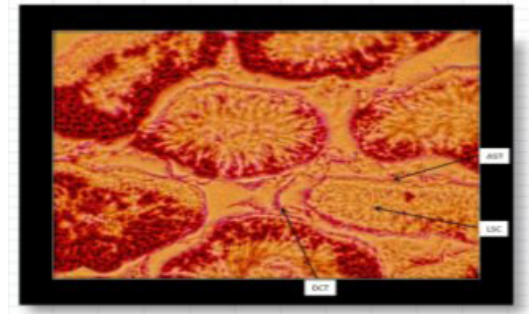

Abbreviations: AST, Atrophic Seminiferous Tubule; DCT, Degenerated Connective Tissue; LSC, Loss of Spermatogenic Cells.

\section{Discussion}

To the best of our knowledge, no previous study has investigated the effect of radiographic fixer effluent on the testes. In the present study, we observed normal testicular tissues in short term/ low dose group (IIa); and short term/high dose group (IIIA) respectively. In contrast, enlarged connective tissues and reduced and irregular shaped sperm cells were observed in long term/ low dose group (IIb); while atrophy of the seminiferous tubules of the testes, degeneration of the connective tissues, and loss of sperm cells were observed in group IIIB exposed to higher dose of effluent over a long-term duration. These findings suggest that the testicular toxicity due to fixer effluent may be time-dependent since the histopathological changes observed in this study occurred after prolonged exposure to fixer effluent.

The mechanism behind the time-dependent cytotoxic effects of fixer efflux on the testicular tissues is not very clear. The seminiferous tubule is the site of the germination, maturation, and transportation of the sperm cells within the male testes [12]. Seminiferous tubules are made up of columnar Sertoli cells surrounded by spermatogenic cells on the epithelial interior and stem cells exteriorly. Spermatogenesis through the process of meiosis takes place within the thin seminiferous tubules [12]. Radiographic fixer effluent has been reported to contain toxic organic and inorganic compounds [13], and the most hazardous of these compounds is silver. In the environment or living organisms, the silver can be present in different forms. The most common is metallic silver, silver salts (ionic silver), silver complexes and colloidal silver. While there are various potential routes of exposure, ingestion appears to be the primary route of entry for silver compounds and colloidal silver proteins [14]. Another important route of silver uptake is often by inhalation through occupational exposure.

Silver nanoparticles have been reported to have toxic effects on the testicular primary cell populations [15]. It has also been documented that silver nano-particles can cross the blood-testis, and blood-brain barriers in mice [16] and rats [17]. Changes that have been observed in silver nanoparticle-exposed cells include reduced rate of proliferation, impaired mitochondria function and induction of apoptosis and/or necrosis $[18,19]$. Silver nanoparticles are capable of entering the nucleus, and as such directly or indirectly interacting with nuclear material $[20,21]$, leading to alterations in DNA integrity or affecting its synthesis. These perturbations may result in inhibition of cellular processes [15]. When such processes concern germline cells, the result may be altered spermatogenesis and fertility, subsequently affecting the reproduction rate and health of the offspring [9].

The lack of cytoarchitectural changes in the lower duration groups in the present study is not well understood. We have previously demonstrated nephrotoxic effects of similar doses of fixer effluent administered to Wistar rats within the same lengths of time [22]. It is noteworthy that exposure to toxic substances depends on a lot of factors such as the pathway of administration (whether the toxin is applied to the skin, ingested, inhaled, injected), the time of exposure (a brief encounter or long term), the number of exposures (a single dose or multiple doses over time), the physical form of the toxin (solid, liquid, gas), the genetic makeup of an individual, an individual's overall health, and many others [23]. Furthermore, body organs that are more susceptible to toxic injury are those particularly associated with absorption, metabolism, waste elimination, as well as those involved with transport, storage and purification of blood [24]. The lack of cytoarchitectural changes in the lower duration groups in the present study may in part be because the testes are not directly involved in the absorption, metabolism, storage, and elimination of toxic constituents of the fixer effluent, which have been associated with cytoarchitectural damage in most body organs. This, therefore, suggests that the long term duration of exposure to fixer effluent is an important factor that determines the extent of the toxic injury on the cytoarchitecture of the testes.

Given the time-dependent and potential reproductive health risk 
of the radiographic fixer effluent, the present findings, therefore, suggest that silver complexes arising from the exhausted fixer effluent should be avoided entirely by using a fixer only partway to exhaustion. This will help deal with the silver complexes that are relatively easy to wash out of paper fibers and minimize the need to dump the harmful silver compounds into the environment. However, when these radiographic effluents are not submitted to processes for reuse, recovery or recycling, they must undergo specific treatment and final disposal. Similarly, there is a strong need to provide increased awareness and guidance and improve the knowledge of specific regulations among professionals involved in health services which generate radiographic processing effluents. Furthermore, training courses on waste management for health services of different institutions should be encouraged and provided by health and environmental agencies.

\section{Conclusion}

In conclusion, the present findings indicated a time-dependent cytotoxic effect of radiographic fixer effluent on the testes of Wistar rats by causing alteration (atrophy) of their seminiferous tubule cells, connective tissues, and sperm cells. These findings suggest that long term exposure to toxic fixer effluent may impair germination, maturation, and transportation of the sperm cells within the male testes and consequently affect male fertility and reproductive health. This calls for treatment and disposal of exhausted fixer effluents to avoid their harmful effects on human health and environment.

\section{References}

[1]. Mosby. Fixer; Mosby's Medical Dictionary. 8th ed. Elsevier; 2009.

[2]. Warren B. Photography. 2nd Ed. Delmar Thomson Learning, Albany, New York;2001.

[3]. Erlick L. Toxic Darkroom Effluents. Heylloyd's Publications; 1998. [cited 2015 April 17]. Available from: www.heylloyd.com.

[4]. Grigoletto JC, Santos CB, Albertini LB, Takayanagui AM. Radiographic processing effluents management status in healthcare centers. Brazilian Radiology. 2011 Oct; 44 (5): 301-7.

[5]. Fernandes AL, Costa PH, Andrade RT, Cavalcante Junior UH, Araújo VS. Analysis of silver content and distribution of generation of radiographic effluents from eastern and southern areas of Natal-RN. In Proceedings of the First Congress of Research and Innovation Network North Northeast Technological Education ;2006.

[6]. Ogbuewu I P, Unamba-Oparah IC, Odoemenam VU, Etuk IF, Okoli IC. The potentiality of medicinal plants as the source of new contraceptive prin- ciples in males. N Am J Med Sci. 2011 Jun;3(6):255-63. PubMed PMID: 22540095.

[7]. Romer AS \& Parsons TS. The vertebrate body. Holt-Saunders International, Philadelphia, PA; 1997. P. 385-86.

[8]. Osinowo OA. Introduction to animal reproduction. 1st edn. Sophic Academic Services Limited, Abeokuta, Nigeria; 2006. 91 p.

[9]. Ema M, Kobayashi N, Naya M, Hanai S, Nakanishi J . Reproductive and developmental toxicity studies of manufactured nanomaterials. Reprod Toxicol. 2010 Nov;30(3):343-52. PubMed PMID: 20600821.

[10]. Lorke D. A new approach to practical acute toxicity testing. Arch Toxicol. 1983 Dec;54(4):275-87. PubMed PMID: 6667118

[11]. National Institutes of Health. Guide for the care and use of laboratory animals. NIH publication 86-23 revised; 1985.

[12]. Inner Body Publications. Human Anatomy: Seminiferous Tubules. Howtomedia Inc., Wilshire, Los Angeles; (Assessed on 30th July 2015). Available at http://www.innerbody.com/anatomy/male-reproductive/seminiferoustubules\#full-description

[13]. Ues K, Piaia L, Schweickardt M. The use of advanced oxidation processes in the degradation of waste developer and $\mathrm{x}$-ray fixer. Proceedings of the XVI Meeting of the Southern Region Chemistry, Blumenau, SC, Brazil; 2008.

[14]. Silver S .Bacterial silver resistance: molecular biology and uses and misuses of silver compounds. FEMS Microbiol Rev. 2003 Jun;27(2-3):341-53. PubMed PMID: 12829274

[15]. Asare N, Instanes C, Sandberg WJ, Refsnes M, Schwarze P, Kruszewski M, et al. Cytotoxic and genotoxic effects of silver nanoparticles in testicular cells. Toxicology. 2012 Jan 27;291(1-3):65-72. PubMed PMID: 22085606.

[16]. Lankveld DP, Oomen AG, Krystek P, Neigh A, Troost-de JA, Noorlander $\mathrm{CW}$, et al.The kinetics of the tissue distribution of silver nanoparticles of different sizes. Biomaterials. 2010 Nov;31(32):8350-61. PubMed PMID: 20684985.

[17]. Gromadzka-Ostrowska J, Dziendzikowska K, Lankoff A, Dobrzyńska M, Instanes C, Brunborg G, et al. Silver nanoparticles effects on epididymal sperm in rats. Toxicol Lett. 2012 Nov 15;214(3):251-8. PubMed PMID: 22982066.

[18]. Schrand AM, Braydich-Stolle LK, Schlager JJ, Dai L, Hussain SM . Can silver nanoparticles be useful as potential biological labels?. Nanotechnology. 2008 Jun 11;19(23):235104. PubMed PMID: 21825779.

[19]. AshaRani PV, Hande MP, Valiyaveettil S. Anti-proliferative activity of silver nanoparticles. BMC Cell Biol. 2009 Sep 17;10:65. PubMed PMID: 19761582.

[20]. AshaRani PV, Low Kah MG, Hande MP, Valiyaveettil S. Cytotoxicity and genotoxicity of silver nanoparticles in human cells. ACS Nano. 2009 Feb 24;3(2):279-90.PubMed PMID: 19236062

[21]. Kruszewski M, Brzoska K, Brunborg G, Asare N, Dobrzyńska M, Dušinská M, et al. Toxicity of Silver Nanomaterials in Higher Eukaryotes. Adv Mol Toxicol. 2011 Jan 1 5:179-259.

[22]. Ugwu AC, Dimkpa U, Ijabor BO, Ewunonu EO, Eteudo AN. Nephrotoxicity of radiographic fixer effluent in wistar rats. J Mol Pathophysiol. 2015;4(4):145-148.

[23]. Wikipedia [Internet]. the free encyclopedia. Toxicity. [cited 2019 Dec 24]. Available from: https://en.wikipedia.org/wiki/Toxicity.

[24]. Ugwu AC, Dimkpa U, Agba ON, Eteudo AN, Anikeh LC, Maduka SO, et al. Splenotoxic effect of radiographic developer effluent on Wistar rats. Int J Res Med Sci. 2016 May;4(5):1625. 